\title{
Serbest Zamanda Medya Ve Türkiye Ailesi
}

\author{
Filiz Aydoğan BOSCHELE *, \\ Esra CIZMECI **
}

\section{Özet}

Günümüzde bireylerin serbest zamanlarında oldukça önemli bir yer tutan medya teknolojileri her ne kadar sürekli iletissim halinde olma izlenimi verse de, kullanıcılarının fiziksel olarak yakınlarındaki insanlarla iletişimlerinin kopmasina neden olmaktadır. Bu etki, aile içi iletişim üzerinde de kendisini göstermektedir. Bireylerin doğumlarından itibaren en yakınlarında olan ve gerek toplumsal, gerekse de bireysel gelişimleri açısından beslendikleri en önemli kurum olan aile içerisindeki iletişimin sağllkl bir biçimde sürdürülmesi, bu kurumun devamlılığ açısından çok önemlidir. Ev içi serbest zamanları dolduran medya teknolojileri, tüm dünyada aile içi iletişimi ve aile bağlarını tehdit eder hale gelmiştir. Aynı zamanda ülkemizde de hem televizyon, hem de internet içeren yeni medya teknolojileri fazlastyla evlere ve bireyin hayatına girmiş; Türkiye'deki aile üyelerinin birbirleriyle olan iletişimlerini azaltarak bireyselleşmelerini artırmıştır. Konu ile ilgili kapsamlı bir literatür değerlendirmesi yapılan bu çalışmada; ev içi serbest zamanda medya kullanımının giderek arttığ ülkemiz hanelerinde, Türk ailesinin de kapitalist değerlerle bireyselleştirildiğine ve bu değerlerle özdeşleştikçe iletişiminin ve devamlılığının tehdit altına girdiğine dikkat çekilmektedir.

Anahtar Kelimeler: Serbest zaman, medya, yeni medya, Türk ailesi, aile içi iletişim.

\section{Media in Leisure Time and Turkish Family}

\section{Abstract}

Although today, media technologies that fill quite a significant place in individuals' leisure times give the impression of being in touch continuously; these technologies actually cause a communication problem with the ones

* Prof. Dr. Filiz Aydoğan Boschele, Marmara Üniversitesi İletişim Fakültesi Radyo Televizyon ve Sinema Bölümü Öğretim Üyesi, faydogan@marmara.edu.tr

** Öğr. Gör. Esra Cizmeci, Yalova Üniversitesi Termal Meslek Yüksekokulu

YIL: 6 SAYI: 11 
physically close to their users. This effect is also seen in on the communication in the family. Sustaining a healthy communication is very important for the continuity of family, the institution that individuals are fed from since their birth, both in terms of their social and individual development. Media technologies that fill leisure times at home are threatening the communication within the family and family cohesiveness all over the world. At the same time, television and new media technologies that include internet, very much entered homes and the lives of individuals in our country as well, and increased the individualization of Turkish family members, by decreasing the communication among them. About this matter, this study gives an extended literature review and points out that in houses of our country, in which the use of media technologies in leisure times is gradually increasing, Turkish family is also individualized by capitalist values and therefore, its continuity and communication is under threat as it identifies with these individualistic values.

Key Words: Leisure time, media, new media, Turkish family, communication in family.

\section{Giriş}

Medya teknolojileri geçmişten günümüze bireylerin hayatında önemli ve yönlendirici bir yer edinmiştir. Bu teknolojiler, özellikle ev içi serbest zaman etkinliği olarak kullanılmaya başlandıktan sonra, bireylerin yaşamlarının en mahrem ve doğal hallerine eşlik eder olmuştur. Ancak; aile üyelerinin ev içi serbest zamanlarda çeşitli aktivitelerle paylaşımlarını ve bağlılıklarını artırması gerekirken, artık bu vakitlerin çoğunu medya teknolojilerini kullanarak harcadıkları ve dolayısıyla da aile içi iletişimlerinden feragat ettikleri gözlenmektedir. Bir diğer gözlem ise, günümüz modern bireyinin, serbest zamanlarının büyük bir kısmını evinde geçirdiğidir. Bunda hem kitle iletişim araçları tarafından dışarıdaki dünyanın tehlikeli gösterilmesinin; hem de evlere giren televizyon ve internet gibi medya teknolojileri aracılığıyla artık eğlencenin, çalışma hayatının ve hatta çalışma dışı yapılması gereken zorunlu etkinliklerin bireylere oturdukları yerden ulaşılabilir kılınmasının bir etkisi söz konusudur. Ayrıca modern dönemden itibaren bireylerin serbest zamanları artmış, artan serbest 
zamanları fazla para harcamak zorunda kalmadan, ev içerisinde medya teknolojileri kullanımıyla geçirmek daha cazip bir hale gelmiş̧ir.

Geleneksel aile yapısının çözülmesi, kentleşme ve modern çalışma koşulları gibi gelişmelerle birlikte, aile içerisinde birlikte yapılan serbest zaman aktiviteleri modern dönemde zaten oldukça azalmıştır. Ailece yapılacak aktiviteler yerine, serbest zamanlara ilişkin harcamaların çoğu; televizyon, internet, cep telefonu, tablet gibi medya teknolojilerine yapılarak evler adeta birer medya merkezine dönüştürülmüsştür. Böylece, medya teknolojileri aracılığıyla evlerinin içinde sürekli dış dünya ile bağlantı halinde olan bireylerin; ailenin diğer üyeleri ile iletişim konusunda kopukluklar yaşamaları kaçınılmaz hale gelmiştir. Bugünün oturma odası, aile üyelerinin hep birlikte oturduğu; ancak kiminin televizyondaki dizi içerisinde kaybolduğu, kiminin akıllı telefonu ile dış dünyaya bağlandığı, kiminin ise bilgisayarı aracılığı ile yapılması gereken işlerini yerine getirdiği bir ortama sahne olmaktadır. Bazı düşünürler, bu sahnenin aile üyelerini birbirlerinden uzaklaştırdığını öne sürerken; bazı düşünürler ise medya teknolojilerinin ailelere sohbet konuları oluşturarak aslında iletişimlerine katk1 sağladığını iddia etmektedirler. Özünde var olan durum ise, bireylerin ya da ailelerin özgürleşmesinin hedeflenmesi değil; en mahrem alanları olan evlerinde geçirdikleri serbest zamanlarında bile medya teknolojileri aracılığıyla kapitalist sisteme hizmet ettirilmelerinin sağlanmasıdır.

Küreselleşen dünya düzeninde bu durumun, Türkiye>deki aileleri de aynı biçimde etkilediği görülmektedir. Bu bağlamda, bu çalışmada hem geleneksel hem de yeni medya teknolojilerin ev içi serbest zamandaki kullanımları odak alınarak; geleneksel kolektif ve paylaşımcı değerlerinden uzaklaşıp kapitalist sistemin belirlediği bireyselleşme yönündeki değerlere yakınlaşan Türk ailelerinin karşı karşıya kaldıkları tehdit unsurlarına dikkat çekilecektir.

YIL: 6 SAYI: 11 


\section{Kavram Olarak "Aile" ve "Serbest Zaman"}

Aile, çocukların gelişim süreçlerinde içinde bulundukları toplum ve kültür ile ilgili temel eğitimi aldıkları yerdir ve modern toplumun oluşturduğu yalnızlık ve yabancılaşma duyguları, aile birlikteliği ile giderilmektedir (Giddens, 2012, s. 279). Aile kurumunun öncelikli görevi, neslin devamını sağlamaktır. Daha sonra, üyelerinin ihtiyaçlarını karşılamak için aile, ekonomik bir işlev edinmektedir. Maddi-manevi her türlü olumsuz durumda aile üyelerinin birbirlerini koruma görevleri de bulunmaktadır. Ayrıca aile kurumu psikolojik bir rol üstlenerek, aile bireyleri arasında kurulan duygusal bağlar aracılığıyla sevgi ve güven duygusu aşılamaktadır. Konumuz açısından daha önemlisi ise; aile üyelerinin birbirlerini eğlendirme, birbirleriyle boş zamanlarını değerlendirme gibi bir görevlerinin de bulunmasıdır (Çimen, 2008, s. 440). Hem çocukların gelişimi ve eğitimi, hem de aile bireylerinin birbirlerine sağlaması gereken psiko-sosyal desteği yerine getirebilmek için özellikle ev içerisinde aile serbest zaman aktivitelerinde bulunmak büyük önem taşımaktadır.

Serbest zaman; yaşamın yemek, içmek, barınmak gibi zorunlu gereksinimlerinin dışında kalan; bireyin kendisini özgür olarak tanımlad1ğ1; kendisini ve toplumsal gerçekliği eleştirel bir bakışla sorgulayabildiği özel bir zamandır. Aristoteles'e göre serbest zaman, toplumun ve kültürün gelişmesine katkıda bulunan özgür bir zaman dilimidir (Aydoğan, 2000, s. 15-21). Bugünkü anlamıyla serbest zaman ise, çalışmadan arta kalan zaman olarak tanımlanabilmektedir (Giddens, 2012, s. 792). Uygarlığın ilk dönemlerinde bir topluluktaki kadın-erkek, genç-yaşlı demeden herkes kendisine göre bir görevi üstlenerek işbirliği içerisinde çalıştığı için, o dönemlerde bugünkü anlamda bir serbest zaman-çalışma zamanı ayrımı bulunmamış; serbest zaman etkinlikleri de çalışmanın içinde yer almıştır. Antik Çağ ve Ortaçağ dönemlerinde çalışma, aile ve topluluk içinde yapılan şenlikli-eğlenceli bir aktivite iken; Sanayi Devrimi sonrası çalışma sıkıcı ve tekdüze bir hale gelmiştir (Aydoğan, 2000, s. 32-86). Modern dönemin kitle kültüründe "çalışma", her türlü dünyevi hazza ulaşmak için bir araç niteliğindedir. Modern birey, çalışma saatlerinde bulamadiğı mutluluğu, insanca yaşama olanağını ve gerçekleştiremediği "insan” kimliğini çalışma dışı zaman ve mekânlarda bulabileceğine inandırılmış; "çalışma", 
$288 \cdot$ YALOVA SOSYAL BILIMLER DERGISI

bu "özgürleştirici" zamanları yaşayabilmek için katlanılan bir araçsallaştırılmış etkinliğe dönüştürülmüştür (Oskay, 2010, s. 180, 399-400). Bireyi biçimlendiren bu dönüşüm, sözkonusu bireylerden oluşan aile kurumuna da etki etmiştir.

\section{Modern Dönemden Günümüze Ailenin Dönüşümü}

Doğduğu andan itibaren kişinin en yakınında olan ve hem sosyal hem de psikolojik anlamda en elzem desteği verme rolünü üstlenen "aile"; önceleri ekonomik, siyasi, sosyal ve kültürel anlamda tüm toplumsal görevleri yerine getiren bir kurum iken; modernleşme ile birlikte ekonomik üretimi fabrikalara, otoritesini siyasal iktidara, dini temsilini de profesyonel din adamlarına devretmiştir. Sanayileşme ile aile kurumu açısından görünürlük kazanan en radikal değişim, işyeri ve evin birbirinden ayrılmasıdır. Böylece aile, yalnızca neslin devamını ve aile bireylerinin psikolojik tatminini sağlayan bir kurum haline dönüşmüştür (Canatan ve Yıldırım, 2013, s. 17, 85-89).

Modern dönemde, bunların yanında aile kurumunda ortaya çıkan önemli değişikliklerden biri de, çocukluğun farklı bir anlam kazanmasıdır. Aries, Centuries of Childhood (1960) adlı eserinde, bugünkü anlamıyla "çocukluk" kavramının, 16. yüzyılda icat edildiğini öne sürmüştür. Ortaçağ döneminde idamları izleyen, cinsel aktivitelere şahit olan ve hatta erken yaşta bu aktivitelere kendileri de dâhil olan çocuklar; 16. yüzyıldan itibaren özel bakım ve koruma gerektiren, sevgiye muhtaç masum varlıklar olarak görülmeye başlanmış ve keskin çizgilerle yetişkinlerden ayrılmışlardır. Önceden "herkesin" arasına karışmış olan çocuklar, artık ilginin merkezine oturmuşlardır. Meyrowitz'e göre özellikle çekirdek ailenin de gelişimiyle çocuk, adeta "duygusal bir yatırım aracına dönüşmüştür" (1985, s. 273-276).

Modern ailedeki bir diğer konum değişikliği ise, kadınlarda görülmüştür. Sanayi öncesi toplumların genelinde üretim evde ya da eve yakın bir yerde yapılmış, ailenin tüm fertleri de tarım ya da zanaat işlerinde çalışmışlardır. Kadınlar, erkek egemenliğinin hakim olduğu siyasal ve askeri alanlardan uzak tutulsalar da, evin içinde önemli bir konumları bulunmuş-

YIL: 6 SAYI: 11 
tur. Modern sanayinin gelişimi ile üretimin fabrikalara kayması, kadınların konumunda değişimlere yol açmıştır. 20. yüzyıla kadar evinin dişında çalışan kadın pek görülmezken, 1. Dünya Savaşı sırasında karşılaşılan işgücü kıtlığı, "kadın içeride, erkek dışarıda" kalıbını bozmuş ve kadınların çalışma hayatına girmesini sağlamıştır (Giddens, 2012, s. 801-804).

Daha önceleri ev, çocukların küçük dünyası olmuş ve toplumun ekranı görevini aile yerine getirmiştir. Aile, toplumla ilgili yalnızca ilgiye değer bulduğu bilgileri çocuğa aktarmıştır. Çocuğa kıyasla evden çok daha rahat dışarı çıkabilen aile büyükleri, dışarıdaki bilgileri çocuğa filtreleyerek getirmişlerdir. Günümüzde ise, eve bilginin giriş biçimi değişmiştir. Bugünün ebeveynleri, binlerce görüntü ve fikirle savaş vermek zorunda kalmışlardır. Dolayısıyla aile içindeki güç ilişkileri de bu şartlarda değişikliğe uğramıştır. Aile, artık bilgi konusundaki tüm gücü elinde tutan yetkili değildir (Meyrowitz, 1985, s. 252-255). 1970’ler sonrasının postmodern toplumunda, modern dönemde kendine has bir kategori haline gelen çocukluk, medya teknolojileri sayesinde yeniden yetişkinlik ile karışmıştır (Giddens, 2012, s. 216). Televizyonun yanında internet ve diğer yeni medya teknolojileri de artık çocukların yetişkinler karşısında eskiye oranla çok daha fazla güç sahibi olmalarını sağlamıştır. Özellikle yeni medya teknolojileri ile dolu bir dünyaya doğan günümüz çocukları ve gençleri, bu teknolojileri kendilerinden önceki nesillerden çok daha iyi kullandıklarından dolayı hem ebeveynlerinden bir adım öne geçmiş, hem de onların kontrolü dışında her türlü bilgiye ulaşabilir hale gelmişlerdir. Günümüzde özellikle taşınabilir ve herkesçe ulaşılabilir olan ve dolayısıyla serbest zamanların her anını kaplayan yeni medya teknolojileri, bu durumun oluşmasında büyük etkiye sahiptir.

\section{Modern Dönemden Günümüze Serbest Zamanda Medya ve Aile}

Giddens'a göre modernite, teknolojinin gelişmesi ve kitle iletişim araçlarından bağımsız düşünülemeyecek bir olgudur, hatta modern kurumların gelişimi ve yayılması da doğrudan bu teknolojilerle bağlantılıdır (2010, s. 40). Günümüzde serbest zamanlar radyo, televizyon, bilgisayar gibi kitle iletişim araçları tarafından kuşatılmıştır (Aydoğan, 2000, s. 15-21). Modern dönemde ailenin mekânı olan ev, kimi düşünürlere göre 
bugün gündelik yaşamın ve kentin yoruculuğundan kaçmak isteyen bireylerin çalışma saatleri dışında sığındıkları bir yer haline gelmiştir. Yoğun çalışma temposundan uzaklaşıp dinlenmek isteyen anne-babalar ve sokakların güvensizliğinden dolayı okul dışı vakitlerini evde geçiren çocuklar, diş dünyayla ilişkilerini ev içi serbest zamanda medya teknolojileri aracılığıyla kurar olmuşlardır (Karakoç ve Taydaş, 2013, s. 211). Medya teknolojilerinde "eğlence"yi bulan bireyler, modern dönemin yorucu temposundan kaçabildikleri zamanlarda kendilerini yenileyeceğini umdukları bu araçlara fazlasıyla yönelmişlerdir. Medya, toplumdaki insanların birbirleriyle ilgili bilgilerini arttırmasına rağmen, bazı kuramcılara göre birbirleriyle birebir bağ kurmalarını gereksizleştirmiştir (Sennett, 2010, s. 363-365).

Modern bireylerin serbest zamanlarını kuşatan en önemli medya teknolojilerinin başında televizyon gelmektedir. Modern dönemin en popüler serbest zaman aracı olarak evlere giren televizyon, gündelik yaşamın monotonluğu ve yoruculuğundan bunalmış bireye evinde iyi vakit geçirten; onu düşünmek ya da hareket etmek zorunda birakmadan, ancak üretkenlikten uzaklaştırarak eğlendiren bir araçtır (Özel, 2015, s. 7). Çakır'a göre kişinin özel yaşamının her alanını kuşatan televizyon, onu kendi hayatıyla ilgili düşünmekten alıkoymakta ve sosyalleşmesine zarar vermektedir. Televizyon gibi medya teknolojilerinin bireyin yaşamındaki rolü sebebiyle gerçek anlamda iletişim giderek gerilemekte; tek taraflı, tek yönlü iletişim egemen olmaktadir (2013, s. 65-81).

Öte yandan, televizyon modern dönemde ailenin, hikayelerini sabırla anlatan bir üyesi olmuştur (Çı̆̆ , 2011, s. 28-29). 1950'lerden itibaren yapılan araştırmalara göre, televizyon Batı ülkelerinde yayılmaya başladıktan sonra, ailenin televizyon etrafında toplanmasını sağlamış ve evi tekrar düzenleyerek bir "aile odası" oluşturmuştur (Livingstone, S., Das, R., 2010, s. 20-21). Televizyonun gelişiyle, evin yapılandırılışı değişmiştir. Televizyonun bulunduğu oda, "oturma odası" olmuş ve burada hiyerarşik sürtüşmeler yaşanmıştır. Televizyon kumandası babanın eline geçmiştir ve spor programları, dizileri geri plana itmiştir. Ancak zamanla evdeki medya teknolojileri çoğaldıkça, yatak odaları özel oturma odaları haline getirilmiş; oturma odası ise ailenin bir araya gelmek istedikleri zaman kullanılır olmuştur (Livingstone, 2010, s. 4-5). 
Televizyonun aile içi iletişim üzerindeki rolü ile ilgili farklı görüşler bulunmaktadır. Evde televizyon izlenmesine olumlu bakan düşünürlerden Meyrowitz'e göre evde tüm ailenin toplanıp televizyon izlemesi, birlikte sinemaya gitmekten daha fazla gündelik hayatın içine işlemiş, daha samimi bir aktivitedir. Ailece izlenen dizilerdeki karakterler, izleyen ailenin bireyleri gibi olmaktadırlar ve böylece izleyici aile, gerçek bir "aile zamanı" geçirmekte olduğu hissine kapılmaktadır (1985, s. 267, 239). Bausinger'e göre de, medya ile ilgilenmek bireysel ve yalnız başına yapılan bir eylem değildir, aksine paylaşılmaktadır. Medya iletişimi ile kişisel iletişimler arasında bir fark yoktur, çünkü medya ile kurulan iletişim, kişilerarası iletişimler için malzeme sağlamaktadır. Nancy Banks Smith'e göre ise, evlerdeki en güzel sohbetler, durum komedileri izlenirken yapılmaktadır. Konuşacak daha iyi bir şeyi olmayan insanlar için televizyon programları ilaç gibi gelmektedir. Lull'a göre, televizyon izlemek konuşmayı azalttığ için kimilerine aile etkileşimini bitiriyor gibi görünebilmektedir, ancak televizyon izlerken aile bireyleri başka zaman yapamayacakları biçimde birbirlerine yakın oturabilmekte, dokunabilmekte ve sarılabilmektedirler. Lull, televizyonun, aile bireylerinin kendi özel gündelik gerçeklikleri içerisinde birbirleriyle etkileşime girebilmeleri konusunda merkezi bir rol oynadığı düşüncesindedir. Çoğu evde televizyon, sohbetlerin ve ev içi faaliyetlerinin adeta bir arka fonu niteliğinde, "doldurucu" göreviyle sürekli açık tutulmaktadır (akt. Morley, 2005, s. 8-22).

Ancak, evde televizyon izlemeye aile içi iletişim açısından olumsuz bakanların odaklandıkları nokta ise; sadece oturma odasında değil, her odada bir televizyon bulunmasından sonra aile bireylerinin birbirlerinden ayrı vakit geçirmeye başlamalarıdır. Zira modern dönemde gençler, bireysel beğeni ve ilgi alanlarını keşfetme konusunda cesaretlendirildiklerinden, ebeveynlerle gençlerin izledikleri programlar farklılaşmıştır. $\mathrm{Bu}$ da, aileyi birbirinden ayrı, bireyselleşmiş zamanlar geçirmeye itmektedir (Livingstone, 2010, s. 4-7).

Öte yandan, postmodern dönem ile birlikte gelişen internet, bilgisayar, akıllı telefon gibi yeni medya teknolojileri ise; ev içinde bireyselleşmiş bir biçimde geçirilen serbest zamanları daha çok teşvik etmiştir. Yeni medya, "sayısallaşan, bilgisayarlarla üretilen ve yayınlanan, ağlar 
üzerinde gezinen bir medya"dır (Eldeniz, 2010: 18). Modern dönemden itibaren bireylerin serbest zamanlarını işgal etmeye başlayan medya teknolojileri; postmodern enformasyon toplumunda gelişen internet, bilgisayar, cep telefonu, tablet gibi yeni medya teknolojilerinin daha mobil, ucuz ve kullanıcıya daha çok fonksiyon sunan araçları ile günümüz bireylerinin vazgeçilmezleri haline gelmişlerdir. 2010 yılında yapılan araştırmalarda, dünya çapında 170 milyon kişisel bilgisayarın satılması ve Amerika'daki satışların 2010 ile 2014 yılları arasında \%69 artması beklendiği görülmüştür. Henüz 2010 yılında iken bile, üç yaş üstü Amerikan vatandaşlarının \%72'sinin interneti kullandığı; 7 ile 17 yaşları arasındaki çocukların $\% 60$ 'ının da kendi cep telefonlarının bulunduğu tespit edilmiştir (Hertlein, 2012, s. 374).

$\mathrm{Bu}$ çarpıc1 sonuçlardan da görüldüğ̈̈ gibi içinde bulunduğumuz çağda serbest zamanda yeni medya kullanımı başta gençler olmak üzere her yaştan birey için giderek artmaktadır. Serbest zamanda yoğun yeni medya kullanımına iyimser bakanlar; çevrimiçi dünyanın yüz yüze etkileşimleri artırdığını ve desteklediğini öne sürmektedirler. Bu teknolojiler sayesinde özellikle ailesinden, sevdiklerinden ve yakınlarından uzakta yaşayan bireyler, onlarla kolaylıkla iletişim kurabilmektedirler. Bu görüşe göre günümüzde mesafeler ve ayrılıklar insanlar için daha katlanılır hale gelmiştir (Giddens, 2012, s. 643). Bazı kuramcılara göre ise medya tüketimi, teknolojilerin getirdiği bireyselleşmeye rağmen, aile içi birliktelik anları sunmaya devam etmektedir. Örneğin cep telefonlarıly iletişim kurmak, aile üyeleri arasında birbirlerini düşündüklerini gösteren "hediyeler" yerine geçebilmektedir (Livingstone, S., Das, R., 2010, s. 4, 35). Ayrıca Skype gibi görüntülü arama programlarının kullanımı, uzak mesafelerden bile olsa çiftlerin ve ailelerin bağları koparmamalarını sağlamaktadır (Hertlein, 2012, s. 377-382).

Diğer yandan, internet teknolojisine daha karamsar bakanlar ise, çevrimiçi iletişimlerde çok zaman harcayan insanların gerçek hayattaki etkileşimlerini azaltacaklarını öne sürmektedirler. Bu görüşe göre özellikle internet teknolojisinin evlerde kullanımının artması, aile bireylerinin birbirleriyle "nitelikli zaman" geçirmelerini de engellemektedir. Ayrıca, internet teknolojisi evin dışı ile içi arasındaki sınırları belirsizleştirerek 
mahremiyete tecavüz etmektedir. Bunun yanında, evdeyken çalışmaya devam etmeyi, ya da aynı evin içindeki aile üyeleriyle değil de, ev dışındaki sosyal çevreyle iletişim kurmayı mümkün kılan internet, bu sebeple aile kurumundan çalmaktadır. Böylece bireyler, ev içi serbest zamanları dolduran yeni medya teknolojileri aracılığı ile evin dışındakilerle, yani uzaktaki insanlarla yakınlaşırken; yakınlarından da uzaklaşır hale gelmişlerdir (Çakır, 2014, s. 319, 71-325).

Avrupa'da yapılan araştırmaların sonuçlarında, ebeveynler ne kadar internet kullanıyorsa, çocuklarının da o kadar kullanmaya eğilimli olduğu ortaya çıkmıştır (Livingstone, S., Das, R., 2010, s. 8, 43). Bugün, ebeveynler fiziksel olarak daha çok çocuklarının yanındadır, ancak zihinsel olarak orada değillerdir; mobil teknolojiler sayesinde başka yerlerdedirler ve çoğu zaman çocuklarından çok, telefonları ile ilgilenmektedirler (Turkle, 2010, s. 183-184, 286). Ebeveynlerin evde yeni medya teknolojilerini yoğun olarak kullanmalarının tek sebebi iş değildir. Artık anne babalar da ev içi serbest zamanlarının çoğunu cep telefonu, internet gibi medya teknolojileri ile geçirir olmuşlardır. Böylece ev içerisinde yalnız kalan gençlerin de bu konudaki örnekleri anne-babaları olmaktadır. Yalnızlaşan ya da aile içinde aradığ 1 huzuru bulamayan çocuklar için bilgisayarlar ve mobil araçlar, ailelerinin eksikliğini gidermek için orada bulunmaktadır (Turkle, 2010, s. 197).

$\mathrm{Bu}$ yönde düşünenlere göre medya teknolojileri, aile birlikteliğini hiçe sayarak, bireysel ilgileri önemsemektedirler (Turrow, 2001, s. 75). Ayrıca; çocukların yatak odalarının kişisel medya teknolojileri ile dolu olması, onların akran kültürüne katılmasını sağlarken, ailelerinden uzaklaştırmaktadır. Taylor ve Harper, artık ev içinde 'iyi geceler' sözünün bile kısa mesajla söylendiğini belirtirken, Flichy bunu 'birlikte, ayrı yaşayan aileler' (living together separately) olarak tanımlamaktadır (akt. Livingstone, 2005, s. 11). Turkle'a göre de teknoloji bağımlısı yaşamlarında insanlar akşam evlerine gittiklerinde, "aile ötesi aileler" (postfamilial families) haline gelmektedirler. Tüm aile bireyleri kendi odalarında, bir bilgisayarla ya da mobil araçla ağa bağlanmış durumdadırlar (2010, s. 229). 
Kitle iletişim araçlarının gelişip yayılmaya başladığı modern dönemden beri aile zaten sisteme bir uyum sağlama aracı olarak hizmet etmiş ve eğlence sanayi tarafindan üretilir olmuştur. Anne-babaların eğitici görevlerinin kendilerinden alınıp başka toplumsal kurumlara devredilmesiyle aile, medya teknolojilerine ve bu teknolojilerin ürettiği ideolojilere karş1 savunmasız kalmıştır (Horkheimer, 1998: 132-135). Birçok düşünüre göre anne, baba ve çocukları birbirinden büyük oranda uzaklaştıran enformasyon toplumunun ve bilgisayar teknolojilerinin asıl amac1; aileyi güçlendirmek değil, bireyi özgürleştirmektir. Ancak birey en mahrem ve korunaklı olması gereken evinde ve düşünüp kendini geliştirmesi gereken serbest zamanlarında kendisine medya teknolojileri aracılığ 1 ile verilen sözde bir özgürlükle, yine kapitalist sisteme hizmet ettirilmektedir. Giderek portatifleşen ve ucuzlayan enformasyon teknolojileri bireylerin yalnız olarak enformasyon ağlarına dalışını mümkün kılmakta, kolektif faaliyetlere yer birakmamaktadır. Hatta enformasyon teknolojileri bireyleri ailenin yarattığ1 "ayak bağlarından” özgürleştirmeyi hedeflemektedir. Ev, bireysel faaliyetler için tercih edilen bir bölge haline gelirken; kolektif bir amaç ya da bir aile değeri duygusu oluşturulmamaktadır. Kumar'ın deyimiyle; "Ev, aile açısından "kalpsiz bir dünyada bir yuva"dan ziyade ücrete tabi olan (ve olmayan) konukların kaldı̆̆ bir otel haline gelmektedir" (1995, s. 190-191). Geleneksel anlamda dünyanın en kolektif ve paylaşımcı değerlerden oluşan aile yapısına sahip Türkiye>deki hanelerde de bu akımın yansımaları görülmektedir.

\section{Osmanlı'dan Bugüne Modernleşirken Bireyselleşen Türk Ailesi ve Serbest Zamanda Medya Teknolojileri}

İçinde bulunulan küresel dünya düzeninde, Türk ailesi de medya teknolojilerinin oluşturduğu gelişmelerden geri kalmamıştır. Türk ailesinin ve serbest zamanının bugün aldığı hali anlayabilmek için, Osmanlı toplumundaki Batılılaşma çabalarına dönmek gerekmektedir. Osmanlı toplumunun ekonomik ve politik yapısı gelenekler tarafından biçimlendirildiğinden, Batılılaşma dönemine kadar Türk ailesi için bireyselleşmeyi teşvik edebilecek bir unsur bulunmamıştır (Belge, 1983: 838-840). Geniş aile tipinde olan ve aile üyeleri arasında büyüklere saygı ve hürmet, küçüklere 
ise şefkat ve sevginin hüküm sürdüğ̈̈ Osmanlı ailesinde; genelde erkeğin dışarıda, kadının içeride olduğu, sakin ve aile üyelerinin birbirlerine bağ11 olduğu bir aile hayatı hüküm sürmüştür. Geleneksel dönemde evlerde bir serbest zaman aktivitesi olarak ince sazların çalındığı, meddah gibi oyunların oynanıp hikayelerin anlatıldığı, oldukça eğlenceli geçen "helva sohbetleri" yapılmıştır. Bu sohbetlerde oynanan oyunlar ile anlatılan hikayeler, toplumsal hafizanın da kuşaktan kuşağa aktarılmasını sağlamıştır (Meriç, 2000: 142). Tanzimat'tan sonra Batılılaşma ile birlikte ise, evlerde gösterişçi tüketim ve materyalist yönelimler baş göstermiştir. Avrupai adab-1 muaşeret kurallarının Türk ailesine entegre edilmeye çalışılması; içki, kumar, dans, kadınların sosyal hayata katılması, çocuklara özel mürebbiyelerin tutulması, erkeklerin çapkınlıklarıyla ün salması gibi yeni durumlarla geleneksel Türk ailesini ve aile içi ilişkileri sarsmıştır (Çimen, 2008, s. 229).

Meriç'e göre Cumhuriyet döneminde yaşanan modernleşmenin en önemli yönü, "Müslüman Türk aileler üzerinde Avrupalılaşmayı gerçekleştirmek istemesidir” (2000: 62). Modernleşme ile birlikte Türk ailelerinde babanın otoritesi diğer aile bireyleri arasında bölüşülmüş, böylece tüm aile bireyleri daha özgür ve serbest bir yaşam sürmeye başlamışlardır (Özer, 2014: 47-49). Diğer yandan, Tanzimat ile birlikte çocuk, okumanın mecbur hale gelmesiyle aileden çıkıp devlet eksenine çekilmiştir. Bunun yanında, üst sınıf aileleri çocuklarını yabancı mürebbiyelerin eline bırakarak Batılılaşmanın getirdiği değişimleri içselleştirmelerini sağlamışlardır. Çocuklar artık baba işini devralmayı bırakmış, ayrıca çok daha geç yaşlarda evlenir olmuşlardır. Dahası, modernleşme ile birlikte evler de biçim değiştirmiş, herkesin zamanla kendine özel bir oda talep etmesi ile özel alan içinde özel alan oluşmuş, bu da Türkiye'de ev içinde ailenin bireyselleşmesinin başlangıcını göstermiş̧tir (Meriç, 2000: 174-181). Cumhuriyet dönemi Türkiyesi'nde yeni ekonomik koşullar ve ideolojik formasyonlar ile birlikte geniş aile dağılmış, ev içi mekanın da buna yardımcı olarak değiştiği gözlenmiştir (Belge, 1983: 849). 1920’li yıllarda görülen kuşaklar arası çatışma ve Batı tarzı yaşama özenerek gençlerin ve kadınların geleneksel değerlerden uzaklaşması ile Türkiye toplumunda "aile buhranı" ifadesi gündeme gelmiştir. Dönemin basılı medyasında, eski ölümsüz ve 
değerli aşklar ile yapılan evlilikler yerine, zenginlik gibi maddi menfaatlerin ön planda olduğu evliliklerin yaygınlaştığı insanlara yansıtılmıştır (Özer, 2014: 222). Sonuç olarak, yaşanılan değer kayıplarıyla birlikte, Türkiye toplumunun geleneksel cemaat yapısı parçalanmış ve aile içerisinde bile sağlıksız bir bireyleşme sürecine girilmiştir (Belge, 2011: 99).

Kuşkusuz, bu bireyleşmenin oluşmasına önemli derecede katkı sağlayan unsurlardan biri de medya olmuştur. Cumhuriyetin ilk yıllarında medya teknolojileri hem halkı eğiterek, bilgilendirerek kültürel kalkınmanın; hem de Kemalist ideolojiyi yayarak propagandanın bir aracı olarak kullanılmıştır. II. Meşrutiyet sonrasında telgraf ve telefonun yaygın olarak kullanılması ile gündelik yaşam daha da hızlanmış ve bunlarla birlikte birtakım sosyal ve kültürel değişmeler baş göstermiştir (Özer, 2014: 44). 1950'lerden itibaren Türkiye'nin gündelik yaşamında eğlencenin ağırlığ1nın da arttı̆̆ı görülmüştür (Belge, 1983: 863).

Eğlence amaciyla Türk ailelerinin ev içi serbest zaman aktivitelerine öncülük eden medya teknolojilerinden ilki kuşkusuz radyodur. Türkiye'de ilk radyo yayınları 1927 yılında gerçekleşmiştir. 1936 yılına gelindiğinde, radyo alıcıları çok pahalı olmasına rağmen Türkiye'de 10.000 dolaylarına radyo alıcısı olduğu belirtilmiştir. 1940 yılında 80.000 civarına yükselen radyo alıcı sayısı, bundan altı sene sonra ise 180.000 'e ulaşmıştır. Günlük yayın saatlerinin artması, söz ve müzik programlarının çeşitlenmesi ve kadınlar-çocuklar-gençler gibi belli kitleler için ayrı programlar yapılması ile radyo Türk ailelerinin serbest zamanlarında popülerleşmiştir (Kocabaşoğlu, 1983: 2733-2736). Radyo, birçok aile için telefon ya da buzdolabından daha öncelikli bir konumda olmuştur. Salonun başlıca köşesine sahip olan radyo, daha sonraları televizyonun da yaptığı gibi oturma düzeninin kendisine göre ayarlanmasını sağlamıştır. Radyonun aileler için bir fenomen haline gelişi, 1950'li yıllarda görülmüştür. 1970'li yıllarda ise televizyonun aynı etkiyi oluşturduğuna tanık olunmuştur. İlk dönemlerde her aile bir televizyona sahip olamadığından, televizyon izleyebilmek için birilerine misafirliğe gitmeye "telesafirlik" adı verilmiş; televizyonda halkın sevdiği popüler programlar gösterilirken sokaklar boşalmış ve bu programların bitmesiyle sokakların tekrar dolduğu görülmüştür (Belge, 1983: 864).

YIL: 6 SAYI: 11 
1960'lı ve 1970'li yıllarda aile içindeki roller de geleneksel Türk ailesine göre farklılıklar göstermiştir. Babanın aile içindeki otoritesi azalırken, çalışma hayatına giren kadının konumu yükselmiştir. Çocukların, kendileri gibi iş bulmaya çalışan babalarına olan bağlılıkları ortadan kalkmıştır. Geleneksel Türk aile değerlerinden bu kopuş, aileyi dağılma tehlikesi ile karşı karşıya bırakmıştır. Artık aile bireylerinin birbirlerini gerçek anlamda tanımaması ve birbirleriyle iletişim kuramaması durumu bu dönemin filmlerinde bile konu edilmiştir (Kaplan, 2015: 97-110).

Türkiye bireyleri ve dolayısıyla da Türk ailesi, özellikle 1980'li yıllardan itibaren serbest zamanda medya teknolojileri kullanımı ile her geçen gün daha çok vakit geçirir olmuşlardır. 1990'lı y1llarda teknolojiye meraklı ve Amerika'da eğitim gören genç gazeteci kuşağı, topluma Amerikan hayranlığını ve kültürünü aşılamış; modernitenin yeni göstergeleri cep telefonları ve internet olmuştur. Köşe yazarları Türkiye gençliğini teknolojik gelişmelerden haberdar etmiş; teknolojiye ayak uydurmak, ondan zevk almak ve onu yaşamın vazgeçilmez bir parçası haline getirmek çağdaşlığın ve seçkinliğin bir özelliği haline gelmiştir (Bali, 2013, s. 23-351). Televizyondan sonra en popüler medya teknolojisi olan internet de, Türkiye halkı tarafından oldukça çabuk benimsenmiş̧tir ve günümüzde de kullanıcı sayısı hızla artmaktadır. Türkiye'ye 1990'larda gelmesine rağmen, 2000'li yıllarda kullanıma sunulan hızlı ve sabit ücretli ADSL teknolojisi ile birlikte internet teknolojisi, 24 saat kullanılabilmek üzere evlere girmiştir (Irak, 2012: 10-11).

Türkiye'deki haneleri kuşatan bu medya teknolojilerinin ev içi serbest zamanda kullanımının, günümüzün aile üyelerini birbirlerinden uzaklaştırma konusunda etkisi büyüktür. Türk Aile Araştırmaları Kurumu'nun 2011 tarihli bir araştırmasına göre Türk ailelerinin serbest zaman faaliyetlerine bakıldığında en başta televizyon izleyiciliğinin (\%60) geldiği görülmektedir. Türkiye'de erkekler de (\%86) kadınlar da (\%73) özellikle akşam saatlerindeki ev içi serbest zamanlarında daha çok televizyon izlediklerini belirtmişlerdir. Özellikle Batı'daki kentlerde televizyonun yalnız izlenme oranlarının artış gösterdiği tespit edilmiştir. Yeni medya açısından bakıldığında ise; internetin en çok (\%58) evlerde kullanıldığı; ve \%53 oranı ile en fazla İstanbul şehrinde evde internet kullanıldığı ortaya çıkmıştır (TAYA, 2011: 107-270). 
2015 yılı Nisan ayında yapılan Hanehalkı Bilişim Teknolojileri Kullanım Araştırması'nın sonuçlarına göre günümüzde evlerin \%69,5'inde (on hanenin yedisinde) internete erişim bulunmakla birlikte; evinde internet kullanan bireylerin oran $1 \% 55,9$ 'dur ve bu oran erkeklerde $(\% 65,8)$, kadınlara göre $(\% 46,1)$ daha fazladır. İnternetin evlerde kullanımı 2015 yıl1na gelindiğinde $\% 87,1$ 'e yükselmiş ve evlerde internetin, $\% 80,9$ oranında sosyal medyaya girmek için kullanıldığ 1 tespit edilmiştir. Ayrıca; Türkiye'de cep telefonu kullanımı ise 1994 y1lında 81,276 gibi bir abone say1sıyla başlamış, 2014 yılına gelindiğinde bu rakam 71,888,416'ya ulaşmıştır (www.tuik.gov.tr, Haberleşme İstatistikleri). Yine aynı kurumun 2015 tarihli araştırma sonuçlarına göre Türkiye'deki hanelerin \%96,8'inde cep telefonu ya da akıllı telefon bulunmaktadır (www.tuik.gov.tr, Hanehalkı Bilişim Teknolojileri Araştırması, 2015)

Türkiye hanelerinde ev içi serbest zamanda medya kullanımı ile ilgili (özellikle nitel) araştırmalar yetersiz olmakla birlikte, mevcut araştırmalardan ortaya çıkan bu çarpıcı değerler, Türk ailelerinin ev içi serbest zamanlarında da medya teknolojileri kullanımının önemli bir yer tuttuğunu açıkça göstermektedir. Bu kadar yoğun medya kullanımının olduğu evlerde, aile içi iletişimin sağlıklı ve aile kurumunun devamlılığına katkı sağlayacak bir biçimde sürdürülebilmesi pek mümkün görünmemektedir. Halbuki, bir çocuğun sağlıklı ve normal gelişiminin sağlanabileceği en önemli mekân, mutlu ve ilgili anne-babaların oluşturduğu aile yuvasıdır. Gerek kardeşler arasında gerekse de anne-baba ve çocuklar arasında bencillik ve kendine odaklı yaşam, aile içi iletişimin önünde bir engeldir (Canatan ve Yıldırım, 2013, s. 141-146). İletişim kurma, aile işleyişinin anahtar yapısıdır. Aile içi krizler dışında bugün aile bireylerini bir araya getirecek tek şey, ortak yapılacak serbest zaman aktiviteleridir (Hodge vd., 2012, s. 288).

Ev içi serbest zamanlarda kapitalist sisteme hizmet eden ve ettiren medya teknolojilerine bağımlı sürdürülen bir yaşam, bireyleri birbirinden uzaklaştırmakta ve doğal olarak da bu bireylerden oluşan ailelerin sürdürülebilirliğini tehdit etmektedir. Her ne kadar yetersiz olsalar da, araştırmaların sonuçları, günümüzde Türkiye hanelerinin de medya teknolojileri ile donatıldığını ve Türkiye'deki aile bireylerinin evlerine gittiklerinde 
diğer aile üyeleriyle geçirmeleri gereken serbest zamanlarını, medya teknolojilerine bağımlı olarak ve evin dışındaki dünyaya bağlanma amacıyla tükettiklerini göstermektedir. Dünyada en güçlü aile bağlarına sahip ülkelerden biri Türkiye dir ve sonuç olarak Türk ailesi de bugün ev içi serbest zamanda yoğun biçimde kullanılan ve aile üyelerini bireysel ilgi ve aktivitelere iterek birbirlerinden uzaklaştıran medya teknolojileri tarafindan tehdit edilmektedir.

\section{Sonuç ve Öneriler}

Günümüzde ev içi serbest zamanlarda medya teknolojileri yoğun bir biçimde kullanılmaktadır ve kimi kuramcılara göre bu, aile bireylerinin birbirleriyle olan iletişimlerini koparmaktadır. Modern dönemin çalışma koşulları ile birlikte zaten birbirleriyle çok az vakit geçirmek zorunda kalan aile bireyleri, ev içinde bir araya gelebildikleri ve etkileşimleri için en faydalı olabilecek serbest zamanları da medya teknolojileri ile geçirince, aile içindeki bağlar zayıflayabilmektedir.

Türkiye toplumunun en kutsal ve kıymetli kurumlarının başında gelen Türk ailesi de daha önceleri saygı, sevgi ve bağll1ık ekseninde biçimlenmesine rağmen; günümüzde bireyselleşmeyi aşılayan kapitalist politikaların, ev içi serbest zamanlarda aile birlikteliğini ikinci plana ittiğini öne sürmek doğru olacaktır. Bu durumun oluşmasında, hem içerikleri hem de kullanım alışkanlıkları ile bireylerin ev içi serbest zamanlarında önemli bir yer edinen medya teknolojilerinin büyük payı bulunmaktadır. İş, okul ya da yorucu ve zaman alan kent hayatı gibi sebeplerden gün içerisinde zaten birbirine ayıracak çok az zamanı kalmış olan Türk ailesinin üyeleri, ev içerisinde de zamanlarının çoğunu televizyon ya da internet içeren akıl11 telefonlar ve tabletler gibi medya teknolojileri ile geçirerek birbirleriyle iletişim kurmaz hale gelmişlerdir. Bu teknolojiler aracıllğıyla evdeyken, evin dışındaki insanlarla sosyalleşme ya da onlardan haberdar olma ihtiyacı hissederek diğer aile üyelerini geri plana iten bireyler, aile birlikteliklerinin sağlıklı bir şekilde yürümesini sağlamak için gerekli olan bağl1lı̆ pekiştirebilecekleri ev içi serbest zamanlarını boşa harcamış olmaktadırlar. 
Horkheimer'ın da belirtttiği gibi, kitle iletişim araçlarının gelişip yayılmaya başladığı modern dönemden beri aile, zaten sisteme bir uyum sağlama aracı olarak hizmet etmiş ve eğlence sanayi tarafindan üretilen bir toplumsal kurum haline gelmiştir. Anne-babaların eğitici görevlerinin kendilerinden alınıp kitle iletişim araçları gibi diğer toplumsal kurumlara devredilmesi ile aile, kapitalist sistemin araçları olan ve gün geçtikçe gelişerek evlerinin her yanını saran medya teknolojileri ile bu teknolojinin ürettiği ideolojiye karşı savunmasız kalmıştır.

Öte yandan, ev içi serbest zamanda medya teknolojileri kullanımı aile içi iletişimi geliştirme potansiyeli taşımaktadır (Lull, 1980; Bausinger, 1984; Smith, 1985; Meyrowitz, 1985; Livingstone ve Das, 2010; Giddens, 2012; Hertlein, 2012) ancak kapitalist ideolojinin bu araçlar aracıllğıyla aile üyelerini bireysel yaşam ve tüketim biçimlerine teşvik etmesiyle birlikte, bu potansiyel çoğunlukla kullanılamamaktadır. Ailece yapılabilecek kolektif serbest zaman etkinliklerinden uzak kalmak, bireylerin kapitalist sistemin bireyselleştirici buyruklarına daha kolay kapılmalarını ve hizmet etmelerini sağlamaktadır. Bu da, aileyi bireyin yaşamı için önemli bir manevi değer olarak konumlandırmaktan ziyade, sunduğu ideolojiyi benimseyerek kendisine hizmet etmesini bekleyen sistemin, deyim yerindeyse işine gelmektedir.

\section{Kaynakça}

Aydoğan, F. (2000). Medya ve Serbest Zaman. İstanbul: Om.

Bali, R. (2013). Tarz-ı Hayat'tan Life Style'a: Yeni Seçkinler, Yeni Mekanlar, Yeni Yaşamlar. İstanbul: İletişim, 10. Baskı.

Belge, M. (Ed.) (1983). “Türkiye'de Günlük Hayat”, Cumhuriyet Dönemi Türkiye Ansiklopedisi içinde, İstanbul: İletişim Yayınları, Cilt: 3, s. 827-860.

Belge, M. (Ed.) (1983). "Türkiye'de Günlük Hayat”, Cumhuriyet Dönemi Türkiye Ansiklopedisi içinde, İstanbul: İletişim Yayınları, Cilt: 4, s. 861-876.

Canatan, K., Y1ldırım, E. (2013). Aile Sosyolojisi. İstanbul: Açı1ım Kitap.

Çakır, M. (2014). Görsel Kültür ve Küresel Kitle Kültürü. Ankara: Ütopya.

Çakır, M. (2013). Medya ve Modernlik. İstanbul: Parşömen.

YIL: 6 SAYI: 11 
Çı̆̆g, Ü. (2011). «George Gerbner», Kadife Karanlık II, s. 11-89, İstanbul: Su.

Çimen, L. (2008). Türk Töresinde Kadın ve Aile. İstanbul: IQ Kültür Sanat.

Eldeniz, L. (2010). “İkinci Medya Çağında Etkileşimin Rolü ve Web 2.0”, Filiz Aydoğan ve Ayşen Akyüz (Ed.), İkinci Medya Çağında İnternet içinde, s.18-35, İstanbul: Alfa.

Giddens, A. (2012). Sosyoloji. İstanbul: Kırmızı.

Hertlein, K.M. (2012). "Digital Dwelling: Technology in Couple and Family Relationships". Family Relations, Vol. 61, s. 374-387.

Hodge, C.J., Zabriskie, R.B., Fellingham, G., Coyne, S., Lundberg, N.R., Padilla-Walker, L.M., Day, R.D. (2012). “The Relationship Between Media in the Home and Family Functioning in Context of Leisure". Journal of Leisure Research, Vol: 44 (3), s. 285-307).

Horkheimer, M. (1998). Akıl Tutulması. İstanbul: Metis Yayınları.

Irak, D., Yazıcığlu, O. (2012). Türkiye ve Sosyal Medya. İstanbul: Okuyan-us Yayınları.

Kaplan, F.N. (2015). 60’lı Yıllar Aile Sineması. İstanbul: Pales Yayınları.

Karakoç, E., Taydaş, O. (2013). “Toplumsal Dönüşüm Bağlamında Sosyal Medya ve Değişen Aile Kavramı”, Ali Murat Kırık ve Ali Büyükaslan (Ed.), Sosyal Medya Araştırmaları 1: Sosyalleşen Birey içinde, İstanbul: Çizgi, s. 207-224.

Kocabaşoğlu, U. (1983). "Radyo”, Murat Belge (Ed.), Cumhuriyet Dönemi Türkiye Ansiklopedisi içinde, İstanbul: İletişim Yayınları, Cilt: 10, s. 2731-2737.

Kumar, K. (1995). Sanayi Sonrası Toplumdan Post-modern Topluma Çağdaş Dünyanın Yeni Kuramları. Ankara: Dost.

Livingstone, S. (2010). "From Family Television to Bedroom Culture: young people's media at home". London: LSE Research Online, Erişim tarihi, 04.07.2015: http://eprints.lse.ac.uk/2772/

Livingstone, S., Das, R. (2010). "Media, Communication and Information Technologies in the European Family". London: LSE Research Online, Erişim Tarihi, 03.07.2015: http://eprints.lse.ac.uk/29788/1/EF8_LSE_MediaFamily_Education.pdf 
Meriç, N. (2000). Osmanlı'da Gündelik Hayatın Değişimi: Adab-ı Muaşeret. İstanbul: Kaknüs Yayınları.

Meyrowitz, J. (1985). No Sense of Place. New York: Oxford University Press.

Morley, D. (2005). Family Television: Cultural Power and Domestic Leisure. Taylor \& Francis e-library.

Özel, S. (Ed.) (2015). Yeni Medya Çă̆ında Televizyon. İstanbul: Derin.

Özer, İ. (2014). Osmanlı'dan Cumhuriyete Yaşam ve Moda. İstanbul: Truva Yayınları, 4. Baskı.

Sennett, R. (2014). Karakter Aşınması. İstanbul: Ayrıntı.

TAYA (2011). Türkiye Aile Yapısı Araştırması. Ankara: Aile ve Sosyal Politikalar Bakanlığı.

Turkle, S. (2010). Alone Together. Basic Books: New York. Erişim tarihi, 12.11.2014: $\quad$ https://play.google.com/books/reader?printsec=frontcover\&output=reader\&id= Dhf5xEZZD0C\&pg=GBS.PR5.w.0.0.0.1

Türkiye İstatistik Kurumu, Hanehalkı Bilişim Teknolojileri Araştırması, 2015, Erişim tarihi, 28.09.2015: http://www.tuik.gov.tr/PreHaberBultenleri. do? $\mathrm{id}=18660$

Türkiye İstatistik Kurumu. Türkiye>de Cep Telefonu Sahipliği Oranları, Erişim tarihi, 07.07.2015:

http://www.tuik.gov.tr/VeriBilgi.do;jsessionid=PGV7Vq1SVXry93TnvLfG915p4bFpWVY2Ljny8Qcy20D21vlMV14J!1229636747?alt_id=1062 


\section{Yalova Üniversitesi Sosyal Bilimler Enstitüsü Dergisi Yazım Kuralları}

1. Dergi'de yayınlanacak makaleler Türkçe veya İngilizce dillerinde olmalı ve Microsoft Word'de yazılmış olmalıdır.

2. Çalışmanın başlığ ilk sayfada, ortada, 12 punto, kelimelerin ilk harfleri büyük ve koyu olmalıdır.

3. Başlığın hemen altında yazarların ad ve soyadları 9 punto ile sağa dayalı olarak yazılmalı, unvan, iletişim bilgileri ve e-posta adresleri ise 9 punto ile dipnotta verilmelidir.

4. Başlık ve yazarların isimlerinin hemen altında 9 punto ile $100-150$ kelimeden oluşan Türkçe Özet, onun altında en az 3 en çok 5 kelimeden oluşan Anahtar Kelimeler yazılmış olmalıdır. Bunların altına İngilizce başlık, Abstract ve Keywords aynı kurallara göre yazılmalıdır.

5. Metin A4 boyutunda, MS Word programında "Times New Roman 11 punto" karakteriyle tek satır aralıklı ve iki yana yaslanmıs olarak yazılir.

6. Sayfa yapısı " $A 4$ " olmalı; sağ, sol üst ve alt kenarlardan " $4 \mathrm{~cm}$ " boşluk bırakılmalıdır. Paragraf başlarındaki boşluk " $1.25 \mathrm{~cm}$ " ve paragraf aralığı "6nk" olmalıdır.

7. Makaleye ilişkin açıklama ve teşekkürler dipnotta yer almalıdır.

8. Doğrudan alıntılar tırnak içinde verilmelidir.

9. Bölüm başlığı ve alt başlıklar ilk harfi büyük, koyu ve sola hizalı olmalıdır. Bölüm başlıkları giriş ve sonuç hariç 1., 2., 3. şeklinde numaralandırılmalıdır. 
10. Tablo, grafik ve şekiller numaralandırılmalıdır. Şekil 1: Grafik 1: Tablo $1 \mathrm{vb}$. Tablo, şekil ve grafiklerde iki noktadan sonra ilk harfleri büyük ve koyu harflerle başlık yazılmalıdır. Tablo, grafik ve şeklin hemen altına 9 punto ile Kaynakça yazılmalıdır.

11. Kaynakça ve atıflarda American Psychological Association (APA) tarzı kullanılmalıdır. Bkz : http://www.indiana.edu/ citing/APA.pdf 